\title{
Structural and electrical properties of Sprayed ZnO:Al thin films
}

\author{
Fawzy A. Mahmoud ${ }^{1 *}$, Hagar Mohamed ${ }^{1}$, M.B.S. Osman ${ }^{2}$ \\ 1- Solid State Physics Dept., National Research Center, P.O. 12311, Dokki, Giza, Egypt \\ 2- Physics Department, Faculty of Women for Arts, Science and Education \\ , Ain Shams University, Heliopolis, Cairo, Egypt
}

\begin{abstract}
Aluminium doped zinc oxide (AZO) thin films were prepared on glass substrates by spray pyrolysis technique. The $\mathrm{Al}$ concentration in the starting solution was varied from $(0$ to 5) wt \%. XRD revealed that both pure and AZO thin films were polycrystalline with hexagonal structure and exhibited (002) preferential orientation. AZO film with minimum electrical resistivity $8.61 \times 10^{-3} \Omega . c m$ were obtained at a doping ratio of $2 \mathrm{wt}$. $\%$.
\end{abstract}

Keywords: Spray pyrolysis; $\mathrm{ZnO}$; structural and Electrical properties.

\section{Introduction}

Thin films of non-stoichiometric and doped metallic oxides of $\mathrm{ZnO}, \mathrm{SnO}_{2}$ and $\mathrm{ZnO}$ : Al etc. had attracted a large attention because of their electrical and optical properties making them suitable for application in different kinds of opto-electronic devices (Rozati. S.M, etal 2007). Among these materials, $\mathrm{ZnO}$ thin films have recently gained much attention due to its advantages over other oxide thin films like ITO, $\mathrm{SnO}_{2}$, etc. These advantages include non- toxicity, low cost, high electrical conductivity and transparency (Zhou.H, etal 2007), $\mathrm{ZnO}$ is a n-type semiconductor with an optical band gap about 3.3 eV consequently; it exhibits a high transmittance in the visible region (Nunes.P, etal 1999). Stoichiometric pure zinc oxide is an insulator while its conductivity could be enhanced by adding Group III metal dopants, such as Al, In and Ga or Group VII dopants like F (Ellmer Klaus, etal 2008).

Corresponding author e-mail: - fawzyhameed@yahoo.com 
Both $\mathrm{Al}$ and $\mathrm{Zn}$ are low cost, non-toxic elements with abundant supply, which make $\mathrm{ZnO}$ :Al more suitable than indium tin oxide as TCO layer in photovoltaic applications. There are several deposition techniques that have been employed to grow $\mathrm{ZnO}$ thin films like chemical vapor deposition (CVD) (Haga.K, etal 1999), magnetron sputtering (Minami.T, etal 2000), pulsed laser deposition (PLD) (Hyuck Bae.S, etal 2000), sol-gel process (Lee.G.H, etal 2003) and spray pyrolysis (SP) (Krunks.M, etal 1995, Paraguay.F, etal 1999). Among these methods, the spray pyrolysis technique has several advantages such as simplicity, safety and the low cost of the apparatus and the raw materials (Jin-Hong Lee, etal 2004). In this paper we investigate the effects of Al doping concentration on the structural and electrical properties of $\mathrm{ZnO}$ thin films.

\section{Materials and Methods}

The pure and AZO thin films were deposited onto glass substrates by using home made spraying equipment at deposition temperature $450{ }^{\circ} \mathrm{C}$. The $\mathrm{Al}$ concentration in the starting solution was varied from (0 to 5) wt. \% keeping all other parameter constant. The spraying solution was $0.3 \mathrm{M}$ zinc acetate dehydrate $\left(\mathrm{Zn}\left(\mathrm{CH}_{3} \mathrm{COO}\right)_{2} .2 \mathrm{H}_{2} \mathrm{O}\right)$ and aluminium chloride $\left(\mathrm{AlCl}_{3}\right)$ dissolved in distilled water mixed with ethanol $\left(\mathrm{C}_{2} \mathrm{H}_{5} \mathrm{OH}\right)$ in the ratio of (1:3), to stabilize the starting solution a few droplets of acetic acid $\left(\mathrm{CH}_{3} \mathrm{COOH}\right) 96 \%$ was added. The X-ray diffraction (XRD) of prepared films was obtained by Philips diffractometer model $(\mathrm{PW} 3040)$ using $\mathrm{K}_{1}$ radiation $\left(\lambda=1.54056 \mathrm{~A}^{\circ}\right)$ in range $2 \theta=\left(30^{\circ}\right.$ $\left.70^{\circ}\right)$. The surface morphology of the films was examined by Atomic force microscopy (AFM) Shimadzu Contact mode Model Wet-SPM. The films composition energy dispersive X-ray analysis (EDX) was examined by JEOL (JXA_840A) electron propmicron-alyzer. The electric properties of deposited films were characterized by Hall effect measurement Lake Shore model -7700A.

\section{Results and Discussion}

The XRD patterns of AZO thin films deposited at various $\mathrm{Al}$ ratios (0 to 5) wt. \% are shown in Fig.1. The XRD analysis revealed that all deposited films are polycrystalline with hexagonal wurtzite structure. The intensity of the (002) peak decreases as the concentration 
of aluminium increases which is possibly due to segregation of $\mathrm{Al}_{2} \mathrm{O}_{3}$ into the grain boundaries, which inhibits the growth of the crystallite size in the films as the Al concentration increases (Nunesa.P, etal 2002). The films with Al concentration less than 2 wt. \% shows the most predominant peak is (002) peak where the (101), (102) and (103) peaks are smaller compared to (002) peak indicating preferred orientation along the c-axis perpendicular to the substrate surface. Films doped with Al more than 2 wt. \%, shows decreasing in its crystallinity and the intensity of (002) peak become comparable with (101) peak and it was hard to detect (102) and (103) peaks. This deterioration of the films crystallinity may be explain due to the formation of amorphous $\mathrm{Al}_{2} \mathrm{O}_{3}$ phase and/or segregation of aluminumin grain boundaries (Dghoughi.L, etal 2010). A similar trend was observed by EI Manounia et al. (El Manounia.A, etal 2006) and Nunesa et al. (Nunesa.P, etal 2002) for the doping range of (1-4) at.\% and (1-5) at.\%.

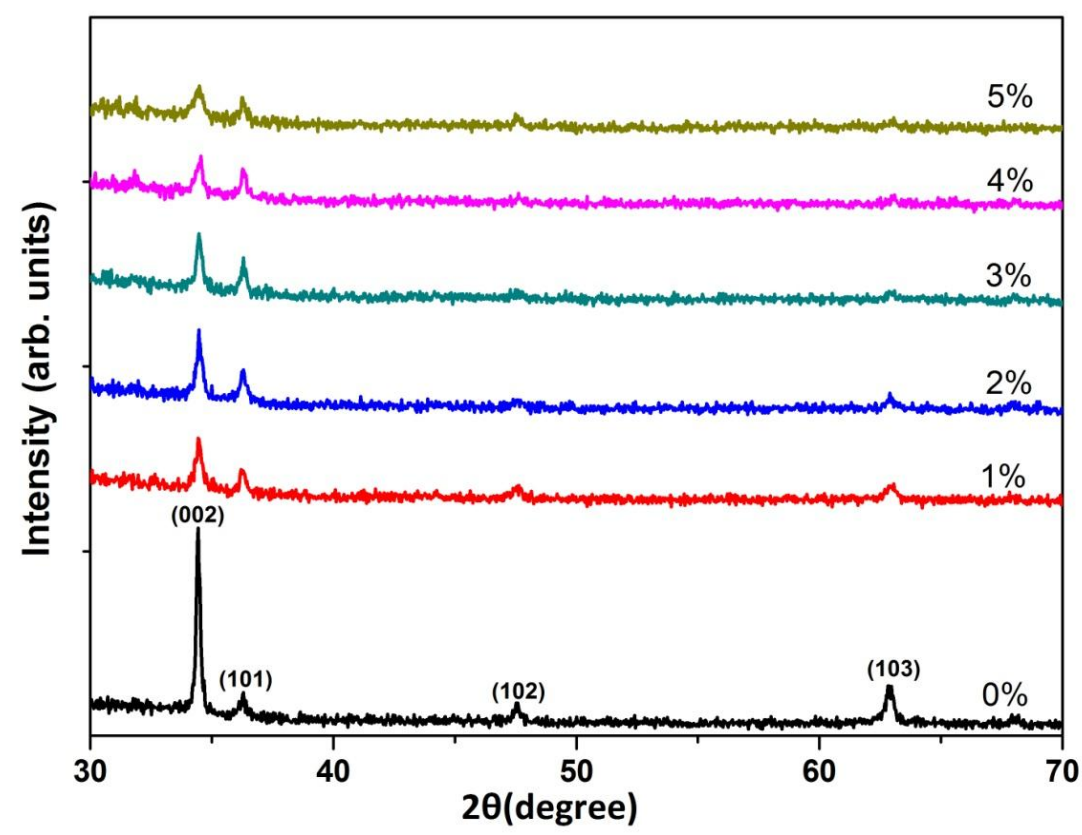

Fig.1 XRD patterns of AZO films with various aluminium concentrations.

The average crystallite size has been calculated using Deby -Scherrer formula (Ohta.Y, etal 1997);

$$
D=\frac{0.9 \lambda}{\beta \cos \theta}
$$


Where $\beta$ is the observed angular width at half maximum intensity (FWHM) of the peak, $\lambda$ is the $\mathrm{X}$-ray wavelength $\left(1.54056 \mathrm{~A}^{\circ} \mathrm{K}_{\alpha 1}\right.$ radiation) and $\theta$ is the Bragg's angle.

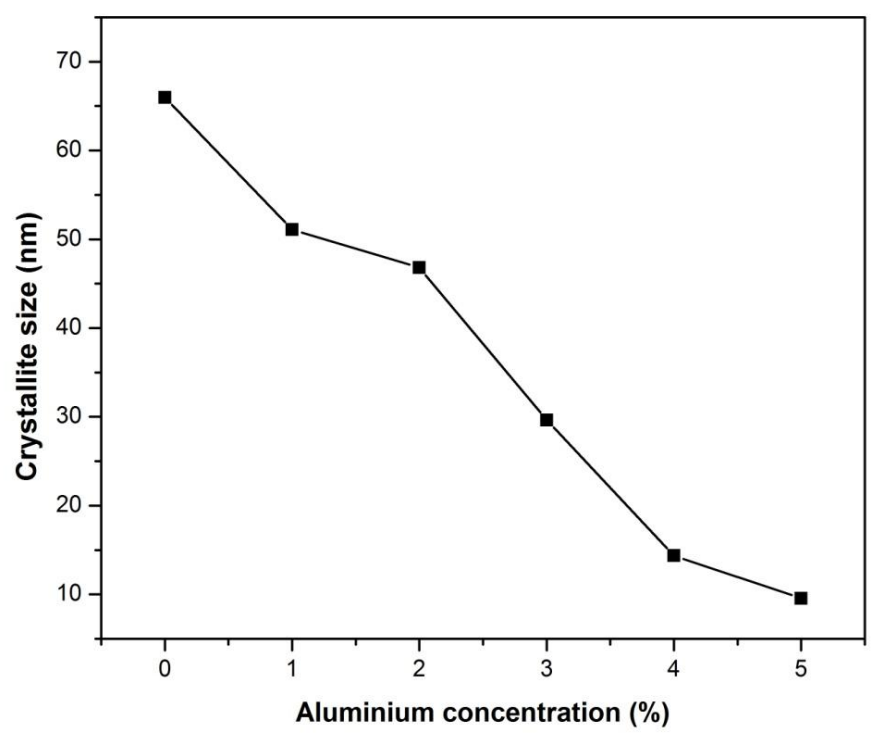

Fig. 2 Crystallite size of AZO films with various aluminium concentrations.

Fig. 2 shows the variation in the crystallite sizes as function of $\mathrm{Al}$ concentration. As it seen the crystallite sizes decreased with the aluminium concentration increase from $65.98 \mathrm{~nm}$ to $9.55 \mathrm{~nm}$. Which may be explain due to the segregation of $\mathrm{Al}_{2} \mathrm{O}_{3}$ into the grain boundaries which inhibits the growth of the particle size in the films as the Al concentration increases (Muiva.C.M, etal 2011).
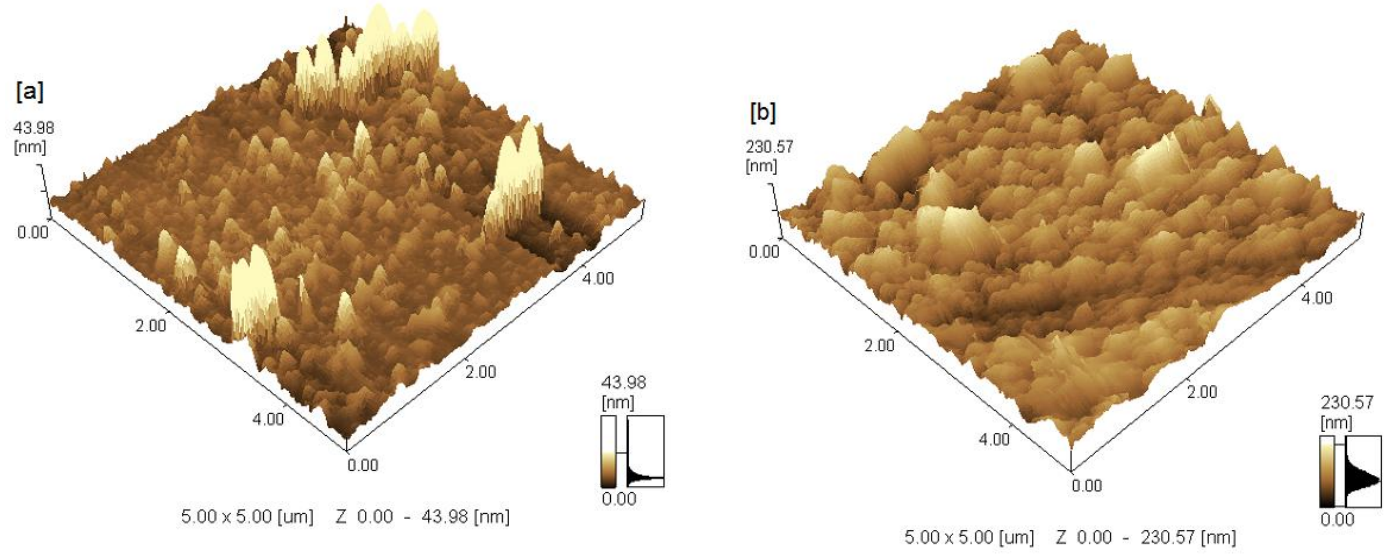

Fig.3 AFM images of $\mathrm{ZnO}$ thin film: [a] pure $\mathrm{ZnO}$ and [b] $\mathrm{AZO}$ thin film $2 \% . w t$ 
The typical AFM images of pure and AZO thin films with Al concentration (2\%.wt) are shown in Fig. 3 . The scanning areas are $5 \mu \mathrm{m} \times 5 \mu \mathrm{m}$. ZnO film exhibit columnar morphology with smooth surface compared to rough surface of AZO film. A similar behavior was observed by J.J. Ding (Ding.J.J ,etal 2009).

The films composition was examined by Energy Dispersive X-ray Spectroscopy (EDX). This study shows the expected elements: $\mathrm{Zn}, \mathrm{O}$ and $\mathrm{Al}$. The calculated weight concentrations for the elements are presented in Table (1).

Table (1): EDX analysis of AZO thin films deposited with various aluminium concentration.

\begin{tabular}{|c|c|c|c|c|c|}
\hline $\mathrm{Al}(\%)$ & $\mathrm{Zn}(\%)$ & $\mathrm{O}(\%)$ & $\mathrm{Al}(\%)$ & $\mathrm{O} / \mathrm{Zn}$ & $\mathrm{Al} / \mathrm{Zn}$ \\
\hline 0 & 52.44 & 47.56 & 0 & 0.91 & 0 \\
\hline 1 & 53.78 & 45.69 & 0.53 & 0.85 & 0.01 \\
\hline 2 & 46.24 & 52.55 & 1.21 & 1.136 & 0.0262 \\
\hline 3 & 42.50 & 55.24 & 2.27 & 1.299 & 0.0534 \\
\hline 4 & 43.60 & 53.0 & 3.40 & 1.216 & 0.078 \\
\hline 5 & 42.87 & 52.9 & 4.22 & 1.234 & 0.099 \\
\hline
\end{tabular}

For pure $\mathrm{ZnO}$ film the $[\mathrm{O}] /[\mathrm{Zn}]$ ratio is smaller than unity indicating a slight oxygen deficiency, which acts as donors leading to n-type conductivity, also shows relatively the best stoichiometrie $([\mathrm{O}] /[\mathrm{Zn}]=0.91)$.A Al doping concentration increase in the prepared solution, the $[\mathrm{Zn}]$ concentrations decrease and $[\mathrm{Al}]$ concentrations increase causing that $[\mathrm{Al}] /[\mathrm{Zn}]$ ratio increase which may be considered as prove that $\mathrm{Zn}^{-2}$ ions is replacement by $\mathrm{Al}^{-3}$ ions leading to n-type conductivity and improvement in its electrical properties (Dghoughi.L, etal 2010).

The electrical properties of AZO films prepared with different Al concentration (0-5) wt.\% were measured and summarized in Table (2). It can be observed that the resistivity decreased from $1.14 \Omega$. cm for pure $\mathrm{ZnO}$ to a minimum of $8.61 \times 10^{-3} \Omega$.cm for films prepared with a starting solution containing 2 wt.\%. The resistivity then started increasing with doping concentration to $1.11 \Omega$. $\mathrm{cm}$ at $5 \mathrm{wt} . \%$ doping. This shows that the resistivity reaches a minimum at $2 \mathrm{wt} . \% \mathrm{Al}$ doping. This result is quite comparable to other reports (Muiva.C.M, etal 2011). 
Table (2): Electrical parameter measurements of AZO films prepared at various Al.

\begin{tabular}{|c|c|c|c|c|}
\hline $\begin{array}{c}\text { Al concentration } \\
(\%)\end{array}$ & $\begin{array}{c}\text { Resistivity } \\
(\Omega . \mathrm{cm})\end{array}$ & $\begin{array}{c}\text { Carrier } \\
\text { concentration } \\
\left(\mathrm{cm}^{-3}\right)\end{array}$ & $\begin{array}{c}\text { Mobility } \\
\left(\mathrm{cm}^{2} / \mathrm{vs}\right)\end{array}$ & $\begin{array}{c}\text { Conductivity } \\
\text { type }\end{array}$ \\
\hline 0 & 1.14 & $3.3 \times 10^{17}$ & 16.6 & $\mathrm{n}$ \\
\hline 1 & $6.54 \times 10^{-2}$ & $4.5 \times 10^{18}$ & 21.2 & $\mathrm{n}$ \\
\hline 2 & $8.61 \times 10^{-3}$ & $3.14 \times 10^{19}$ & 23.1 & $\mathrm{n}$ \\
\hline 3 & $3.05 \times 10^{-2}$ & $1.13 \times 10^{19}$ & 18.1 & $\mathrm{n}$ \\
\hline 4 & $8.69 \times 10^{-1}$ & $3.34 \times 10^{18}$ & 2.15 & $\mathrm{n}$ \\
\hline 5 & 1.11 & $2.62 \times 10^{18}$ & 2.16 & $\mathrm{n}$ \\
\hline
\end{tabular}

When a small amount of $\mathrm{Al}$ was introduced into the $\mathrm{ZnO}$ film, the $\mathrm{Al}$ was ionized into $\mathrm{Al}^{3+}$ and substituted for $\mathrm{Zn}^{2+}$. Thus, one free electron was produced from one zinc atom replaced by an aluminium atom. Small amounts of aluminium introduce large numbers of free electrons in the doped films, and the conductivity therefore increases. But further increase of aluminium concentration ( $>2 \mathrm{wt} . \%)$ does not further increase the conductivity. Excess amount of aluminium cannot be accommodated into $\mathrm{ZnO}$ lattice due to its limited solid solubility and therefore form neutral aluminium oxide and segregates in the grain boundaries (Gomez-Pozos.H, etal 2007). Therefore, the amount of electrically active Al atoms in the film is reduced when the Al doping is high and excess dopant lead to build up of carrier traps in the lattice reducing their mobility. In the case of the films deposited with the optimum Al ratio ( 2 wt.\%), we suppose the solubility limit of Al into $\mathrm{ZnO}$ lattice is reached hence $\mathrm{Al}$ is uniformly distributed inside the grains and a continuous film is obtained, and consequently the electrical resistivity reaches its minimum value (Muiva.C.M, etal 2011).

\section{Conclusion}

Highly transparent conducting AZO thin films were successfully prepared on glass substrate by spray pyrolysis technique. The influences of Al doping concentration on structure and electrical properties were studied. All prepared films were polycrystalline with hexagonal wurtzite structure. The film obtained with Al concentration 2 wt. \% show best crystallinity and minimum resistivity $8.61 \times 10^{-3} \Omega . \mathrm{cm}$. 


\section{References}

Dghoughi.L, Ouachtari.F, Addou.M, Elidrissi.B, Erguig.H, Rmili.A, Bouaoud.A, Physica B, 405, 2277-2282 (2010).

Ding .J.J, Ma.S.Y, Chen.H.X, Shi.X.F, Zhou.T.T, Mao.L.M, Physica B, 404, 2439-2443 (2009).

El Manounia.A, Manjo'nb.F.J, Mollar.M, Marı'b.B, Go'mez.R, Lo'pez.M.C, Ramos Barradod. J.R, Superlattices Microstruct, 39, 185-192 (2006)

Gómez-Pozos.H, Maldonado.A, Olver.L, de la.M, Mater.Lett, 61, 1460-1464 (2007).

Haga.K, Katahira.F, Watanabe.H, Thin Sold Films, 343, 145 (1999).

Hong- Lee.J, Ok-Park.B, Materials Science and Engineering.B, 106, 242-245 (2004).

Hyuck Bae.S, Yeol Lee.S, Young Kim.H, Appl.Surf.Sci, 168, 332 (2000).

Klaus.E, Andreas.K, Bernd.R, Springer,New York, 140 (2008).

Krunks.M, Melikov.E,Thin Solid Films, 33, 270 (1995).

Lee.G.H, Ko.K.H, Park.D.O, Cryst Growth, 247, 119 (2003).

Minami.T, Yamamoto.T, Miyata.T, Thin Solid Films, 366, 63 (2000).

Muiva.C.M, Sathiaraj.T.S, Maabong.K,Ceramics International, 37, 555-560 (2011).

Nunesa.P, Fortunatoa.E, Tonelloa.P, Braz Fernandesa.F, Vilarinhob.P, Martins.R, Vacuum, 64, 281-285 (2002).

Nunes.P, Malik.A, Fernandes.B, Fortunato.E, Vilarinho.P, and Martins.R, Vacuum, 52, 45-49(1999).

Ohta.Y, Haga.Y, Abe.Y, Jpn. J. Appl. Phys, 36, L1040-L1042 (1997).

Paraguay.F, Estrada.D.W, Acosta.L.D.R, Antrade.N.E, Yoshida.M.M,Thin Solid Films, 350, 192(1999).

Rozati.S.M, Akesteh.Sh, Materials Characterization, 58, 319-322 (2007).

Zhou.H, Yi.D, Yu.Z, Xiao.L, Li.J, Thin Solid Films, 515, 6909 (2007). 


\section{الملخص باللغة العربية}

الخواص التركبية و الكهربائية للاغشية الرقيقة من أكسيد الزنك المطعم بالالومنيوم

\section{فوزى ـا.محمود”"1، هاجر محمد1، مسرات بكر عثمان2}

1-قسم فيزياء الجو امد، المركز القومى للبحوث، الرقم البريدى 12311، الدقى ، الجيزة، مصر

2-قسم الفيزياء، كلية البنات للآداب و العلوم و التربية، جامعة عين شمس، هليوبلس، القاهرة، مصر

تم تحضير عينات من أكسيد الزنك النقى و المطعم بالالومنيوم بطريقة الأحلال الحرارى للرذاذ. و قد نم در اسة تأثثر

تركيز الالومنيوم على كل من الخواص التركبية و الكهربية حيث أظهرتالنتائج أن الأغشية المحضرة متعددة التبلور و

أن نسبة التبلور تقل و تضمحل بزيادة نسبة عنصر الالومنيوم. كما أظهرت النتائج أن الالأغشية الرقيقة من أكسيد الزنلك المطعم تمتاز بتوصيلية كهربائية عالية من النوع السالب و قد لوحظ أن أفضل خو اص كهربائية قد تحققت عند 